\title{
Working Conditions and Salary as Correlates of Teachers' Productivity in Government-Owned Secondary Schools in Emure Local Government Area of Ekiti State, Nigeria
}

\author{
Bolarinwa Dapo Alonge (Corresponding author) \\ Department of Educational Management \\ Ekiti State University, Ado-Ekiti, Nigeria \\ E-mail: dapo.bolarinwa@eksu.edu.ng
}

Onajite Godwin Onnoh

Department of Vocational and Technical Education

Ekiti State University, Ado-Ekiti, Nigeria

E-mail: onajitego@gmail.com

Ogunmilade Johnson Olusesean

Department of Vocational and Technical Education

Ekiti State University, Ado-Ekiti, Nigeria

E-mail: ogunmilade123@gmail.com

Olaoye Ajiboye Ojo

Department of Vocational and Technical Education

Ekiti State University, Ado-Ekiti, Nigeria

E-mail: ajiboye@gmail.com 
Olaniyi Oladele Nathaniel

Department of Vocational and Technical Education

Ekiti State University, Ado-Ekiti, Nigeria

E-mail: oladelenathaniel2@gmail.com

Received: February 5, 2020 Accepted: March 15, 2020 Published: March 25, 2020

doi:10.5296/jei.v6i1.16400ＵRL: https://doi.org/10.5296/jei.v6il.16400

\begin{abstract}
The poor performance of candidates in external examination between 2014 and 2018 could be an indication of low productivity of teachers. The research study examined the influence of working conditions and salary on teachers' productivity in government owned secondary schools in Emure Local Government Area of Ekiti State, Nigeria. The descriptive research of the survey type was employed for the research study. The population for this research study was seven government-owned secondary schools while the sample was four government-owned secondary schools. The research study found out the relationship between working conditions and teachers' productivity; salary and teachers' productivity in government-owned secondary schools in Emure Local Government Area of Ekiti State, Nigeria. Validated instruments tagged, "Working Conditions and Salary Questionnaire" (WCSQ) and "Teachers' Productivity Questionnaire" (TPQ) were used to collect data from sample of 80 respondents. Simple random sampling technique was used to select four secondary schools while, proportional sampling technique was used to select 80 teachers. The research study revealed that there was significant relationship between working conditions and teachers' productivity; salary and teachers' productivity. This research study has shown that working conditions and salary had influence on teachers' productivity.
\end{abstract}

Keywords: Working conditions, Salary, Productivity, Teachers' productivity, Public secondary schools

\title{
1. Introduction
}

Productivity is a measure of how efficient, a given set of resources is utilised to achieve an organisational goals and objectives. Teachers' productivity is an index used to describe teachers' effectiveness and efficiency with regards to the relationship between the characteristics of teaching acts and the effect they have on educational outcome through classroom teaching. According to Oguntoye (2002) cited in Togunloju (2015), the success of any school organisation in achieving its goals and objectives depends largely on the efficiency and effectiveness of its administrator and teachers.

The poor result of the candidates who sat for the West African Schools Certificate Examination in Emure Local Government Area of Ekiti State, Nigeria between 2014 and 
2018 could be an indication of low productivity of teachers (Ekiti State Ministry of Education). The researchers observed that some teachers in Emure Local Government Area of Ekiti State government-owned secondary schools are no longer taking time to deliver lessons in an interesting manner, do their work with zeal, show little concern over the progress of the students in examination and attend school functions regularly.

It has also been observed that teachers' productivity is dwindling in government owned secondary schools in Emure Local Government Area of Ekiti State, Nigeria. According to El-Gohany and Aziz (2014), the most factors affecting labour (teachers inclusive) productivity in Egypt are, work experience; incentives; the materials available and handling with ease; leadership and management efficiency; and the efficiency of the supervision work.

Working conditions refer to work environment and all circumstance in existence that can affect teachers in schools. This include, hours spent on job, physical aspects, rights that are legal, assigning of responsibility, human development and so on. In another vein, working conditions come into play by the relationship of teachers with their schools' culture, and this includes physical as well as psychological working conditions. Therefore, working conditions can be adopted as the working environment as aspect of teachers' employment terms and conditions of employment.

It has been observed that working conditions components such as, availability of working tools and equipment, presence of adequate working space needed to accomplish various tasks, leadership styles that give freedom of expression of personal desires, innovation and creativity, social work availability of different forms of motivators, a feeling of recognition and so on, were not adequately available. Teachers could be sitting in cluster of more than ten in a single room called, common room. Modern tools and equipment like interactive board could not be provided. Bornstein (2003) stated that in organisations where workers are exposed to stressful working conditions, productivity is influenced negatively and that there is a negative influence on the delivery of service. On the other hands, if working conditions are of quality, productivity increases and there is positive influence on the delivery service. It appears, some of the school heads are dictatorship. It also appears, some of the school heads are involved in nepotism and favouritism. Noble (2003) noted that extra attention should be given to identifying and dealing with working conditions because, when workers have negative perception to their environment, they sometimes suffer from very serious stress.

It has been established by research that pay-performance productivity of workers are paid with high pay wages. This practice is highly based on the scientific management approach which assumes that financial incentives were motivating indices that stimulate worker's productivity. According to Ismail (2006), the principles of scientific management approach were laid upon a foundation of one-sided development of a fair incentive pay system. On the other hand, Dessler (2005) opined that financial incentives reflect fair representation of worker's effort would improve efficiency and productivity if workers perceive fairness in it.

One main reason why people work is to earn income in monetary terms. This is necessary to meet some personal and domestic needs such as, clothing, feeding, payment of rent, payment of school fees and so on as salaries have a large motivating tendency in them. Increment in 
salaries and wages do not matter but prompt and regular payment of them. The researcher observed that teachers' meagre salaries are not being paid promptly and regularly which could result into ridiculous practices like, examination malpractices with the intention of earning more money to meet some life challenges like, strike actions and so on; hence, resulting into their low productivity.

According to Yesufu (1984) cited in A. Y. S. Ali, A. A. Ali, and Adan (2013), the nature of the physical conditions under which workers work is so imperative to output, offices and factories that are too hot and ill-ventilated are hindrance to efforts. They investigated the relationship between working conditions and workers' productivity in manufacturing companies in Sub-Sahara African context: A case study of Somalia, found out a positive correlation between working conditions and productivity. Ejiogu (2001) observed that salary increment enhance teachers' commitment and performance. Fabiyi (2000) also observed that salary is the best predictor of teachers' productivity while Okendu (2012) identified payment of salary as a satisfier and a hygiene factor. Ofoegbu (2004) in his study on salary and its adaptation to classroom effectiveness and improvement of schools found out that teachers' salary should be paid regularly among other benefits. Yahya and Fasasi (2015) in their study, teachers' job performance stress as a correlate of job satisfaction in selected secondary schools in Ife Central Local Government Education zone of Osun State, Nigeria found out that teachers' income have effect on their performance. In other words, if by any means irregular payment of salary influences teachers' attendance to class, students' achievement suffers.

Productivity of workers has been established to be directly related to workers' motivation. This claim was supported by different management theories since the works of Fredrick Taylor on "the principles of scientific management" in 1911 and Henry Grantt on "'works, wages and profit" in 1913. Maslow (1970) said that people work to survive and live through financial reward, to make new friends, to have job security, for a sense of achievement, to feel important in the society, to have sense of identity, and most especially to have job satisfaction. All workers that have job satisfaction are high performers in their different workplaces. Taylor (1911) opined that the most important motivator of workers is salary and wages when he opined that "non-incentive wage system encourages low productivity." He also opined that if workers receive the same wage irrespective of their individual contribution to the goal, their work will be reduced and that workers think working at a higher rate may result into hiring few workers which may discourage workers to improve on their work.

\subsection{Herzberg's Two-Factor Theory}

This is equally called, the motivation-hygiene theory. This is because; the five different levels identified by Maslow were collapsed into only two levels: Motivators and hygiene factors. According to Herzberg (1968) cited in Ajayi and Ayodele (2002), the factors that were mentioned as leading to job satisfaction (satisfiers) were found to be unrelated to those resulting in job dissatisfaction (dissatisfiers).

(A) Motivator or Satisfiers: These include responsibility, achievement, work itself, recognition and advancement. There are roughly equivalent to Maslow's higher-level needs. 
(B) Hygiene Factor or Dissatisfiers: These are things that will not simply motivate the workers, but from time to time, serve as dissatifiers when they are not present. This hygiene factor is a none-motivator of workers. Working conditions are related to this theory because, the absence of none-motivator brings a very high negative feelings and their presence generally bring workers satisfaction. These include, working conditions, salary, company policy, technical supervision, interpersonal relations, status and security. These are preventive and environmental in nature. They prevent dissatisfaction and are roughly equivalent to Maslow's lower level needs.

\subsection{Work Environment/Working Conditions}

A peaceful environment devoid of rancour and where there is unity and cooperation provides avenue for motivation. The other extreme where there is intrigue, rumour mongering and discord do not support motivation. An atmosphere of uncertainty is inversely related to motivation. It is the duty of management to prevent these negative environment tendencies from disrupting the tone and subsequent staff motivation in their organisations.

Apart from the psycho-social environment, the physical environment in terms of its beauty and comfort could be a source of satisfaction and motivation. Poorly planned, unhealthy and dirty work environment cannot be a source of motivation to teachers in the school system. Well-cut lawns, beautiful flowers and building structures has been known to make teachers and students proud. Thus, the physical structures and biological environments are important in providing a measure of satisfaction and motivation to workers.

It can be inferred from the literature reviewed that, working conditions and salary are related to teachers' productivity but from time to time, they serve as satisfiers when they are not present.

\section{Method}

The descriptive research of the survey type was used for this study. The population of this research study consisted of seven government-owned secondary schools in Emure Local Government Area of Ekiti State, Nigeria. The sample for this study consisted of four government-owned secondary schools and 80 teachers. For the selection of four government-owned secondary schools, simple random sampling technique was employed and for the selection of 80 teachers, proportional random sampling technique was employed.

Two sects of instrument, "Working Conditions and Salary Questionnaire" (WCSQ) and "Teachers' Productivity Questionnaire" (TPQ) were designed and adopted to collect data for this study. A 4-point rating scale was used for the instruments. The instruments were shown to specialists in the field of Tests and Measurement and Educational Management who checked and read the contents for adequate coverage of the topic and clarity of the items for face and content validities. The reliability co-efficient (r) calculated were 0.75 and 0.81 for WCSQ and TPQ respectively through the test-re-test method, which was high enough to ensure the reliability of the instruments. The two sets of instrument were administered personally by the researchers. The hypotheses formulated were tested at 0.05 level of significance using Pearson product moment correlation statistics. 


\section{Results}

The null hypotheses formulated for the study were tested as shown in Tables 1 and 2.

Table 1. Test of relationship between working conditions teachers' productivity in public secondary schools

\begin{tabular}{|l|l|l|l|l|l|}
\hline Item & $\mathbf{N}$ & $\overline{\mathbf{X}}$ & SD & r-cal & r-tab \\
\hline Working conditions & 4 & 28.91 & 4.17 & \multirow{2}{*}{0.92} & \multirow{2}{*}{0.75} \\
\cline { 1 - 4 } Teachers' productivity & 4 & 62.91 & 4.66 & & \\
\hline
\end{tabular}

Note. $\mathrm{P}<0.05$ (significant result).

The above table shows the relationship between working conditions and teachers' productivity. The result obtained from the analysis shows that r-calculated (0.92) is greater than r-table (0.75). The null hypothesis earlier formulated is therefore, rejected. This then signifies that, there was significant positive agreement between working conditions and teachers' productivity.

Table 2. Test of relationship between salary and teachers' productivity in public secondary schools

\begin{tabular}{|l|l|l|l|l|l|}
\hline Item & $\mathbf{N}$ & $\overline{\mathbf{X}}$ & SD & r-cal & r-tab \\
\cline { 1 - 5 } Salary & 4 & 6.59 & 1.02 & \multirow{2}{*}{0.96} & \multirow{2}{*}{0.75} \\
\cline { 1 - 4 } Teachers' productivity & 4 & 6.29 & 4.66 & & \\
\hline
\end{tabular}

Note. $\mathrm{P}<0.05$ (significant result).

The above table shows the relationship between salary and teachers' productivity. The result obtained from the analysis shows that $r$-calculated (0.96) is greater than r-table $(0.75)$. The null hypothesis earlier formulated is therefore, rejected. This then means that, there was significant positive agreement between salary and teachers' productivity.

\section{Discussion}

The research study revealed that there was significant positive agreement between working conditions and teachers' productivity. This means that, working conditions will enhance the productivity of teachers. This might be as a result of availability of working conditions. This finding supports that of A. Y. S. Ali, A. A. Ali, and Adan (2013) who investigated the relationship between working conditions and workers' productivity in manufacturing 
companies in Sub-Sahara African context: A case study of Somalia, found out a positive agreement between working conditions and productivity; El-Gohany and Aziz (2004) who opined that the most factors affecting labour (teachers inclusive) productivity in Egypt are, work experience; incentives; the materials available and handling with ease; leadership and management efficiency; and the efficiency of the supervision work; Noble (2003) who noted that extra attention should be given to identifying and dealing with working conditions because, when workers have negative perception to their environment, they sometimes suffer from very serious stress; and Yesufu (1984) cited in A. Y. S. Ali, A. A. Ali, and Adan (2013) who opined that the nature of the physical conditions under which workers work is so imperative to output, offices and factories that are too hot and ill-ventilated are hindrance to efforts.

The research study also revealed that there was positive agreement between salary and teachers' productivity. This means that, salary will enhance the productivity of teachers. This might be because of regular payment of teachers' salary. This finding is in support of Ejiogu (2001) who observed that salary increment enhance teachers' commitment and performance; Yahaya and Fasasi (2015) who found out that teachers' income have effect on their performance; Taylor (1911) who opined that the most important motivator of workers is salary and wages when he opined that "non-incentive wage system encourages low productivity". He also opined that if workers receive the same wage irrespective of their individual contribution to the goal, their work will be reduced and that workers think working at a higher rate may result into hiring few workers which may discourage workers to improve on their work; and Fabiyi (2000) who also observed that salary is the best predictor of teachers' productivity; El-Gohany and Aziz (2004) who asserted that the most factors affecting labour (teachers inclusive) productivity in Egypt are, work experience; incentives; materials available and handling with ease; leadership and management efficiency; and the efficiency of the supervision work.

\section{Acknowledgements}

We sincerely appreciate the schools and teachers sampled for this study in Emure Local Government Area, Nigeria, for their assistance and cooperation during the administration of the instruments. We acknowledge with thanks and immense gratitude, all the sources cited in this study and the ideas borrowed from published and unpublished sources. We cannot but express our sincere appreciation to Dr. Bolarinwa Dapo Alonge for typing the manuscript. We sincerely thank the Education Tax Fund for providing enough funds for research despite the fact that we were unable to access the funds. God bless the agency! Amen.

\section{References}

Ajayi, I. A., \& Ayodele, J. B. (2002). Fundamentals of Educational Management. Lagos, Nigeria: Dolphin Publishers.

Ali, A. Y. S., Ali, A. A., \& Adan, A. A. (2013). Working conditions and employees productivity in manufacturing companies in Sub-Sahara African context: A case of Somalia. Educational Research Journal, 2(2), 67-78. 
Bornstein, T. (2007). Stressful working conditions. Journal of Cognitive Neuroscience, 19(3), 468-478. https://doi.org/10.1162/jocn.2007.19.3.468

Dessler, G. (2005). Human resource management. New Jessey: Pearson Education Incorporation.

Egiogu, A. (2001). School personnel management: A Nigerian perspective. Lagos: University Press.

El-Gohany, K. M., \& Aziz, R. F. (2014). Factors influencing construction labour productivity in Egypt. Journal of Construction Engineering and Management, 30(1), 1-9. https://doi.org/ 10.1061/(ASCE)ME.1943-5479.0000168

Fabiyi, O. B. (2000). Increasing productivity in Nigeria. Proceeding of the first National Conference on productivity. Lagos, Nigeria: Macmillan Publishers.

Ismail, A. (2006). Relationship between pay distribution system, distributive justice and work attitudes and behavours within Malysian institutions of higher learning. UNITARE-Journal, $3(1), 1-22$.

McGregor, D. (1960). Human side of enterprise. New York: McGraw Hill.

Noble, A. (2003). Building health promotional work setting! Identifying the relationship work characteristics and occupational stress. Promotional International Journal, 18(4), 351-359. https://doi.org/10.1093/heapro/dag407

Ofoegbu, F. I. (2004). Teacher motivation: A factor for classroom effectiveness and school improvement in Nigeria. Gale Group. Retrieved, August 15, 2005, from http//:www.findArticles.com

Okondu, J. N. (2012). Incentive scheme and job performance. Owerri, Nigeria: Unique Prints.

Saida, J. A. (2004). The teaching profession: A manual for professional excellent. Ibadan, Nigeria: Spectrum Books.

Taylor, F. W. (1911). Principles of scientific management. New York: Harper and Row.

Togunloju, T. (2015). School factors as correlates of teachers' productivity in secondary schools in Osun State, Nigeria (Unpublished Master's Thesis, Faculty of Education, Ekiti State University, Ado-Ekiti, Nigeria).

Yahaya, B. Y., \& Fasasi, G. (2015). Teachers' job performance stress as a correlate of job satisfaction in selected secondary schools in Ife Central Local Government education zone of Osun State, Nigeria (Unpublished Master's Thesis, Faculty of Education, Obafemi Awolowo University, Ile-Ife, Nigeria). 


\section{Copyright Disclaimer}

Copyright for this article is retained by the author(s), with first publication rights granted to the journal.

This is an open-access article distributed under the terms and conditions of the Creative Commons Attribution license (http://creativecommons.org/licenses/by/3.0/). 